\section{$P-329$ 凌譄上皮内癌の臨床病理学的検討}

\author{
愛知医科大学 11 蒲郡市民病院 ${ }^{2}$ \\ 本多靖明" \\ 水本裕之") \\ 深津英捷 ${ }^{1)} \cdot$ 羽田野幸夫"
}

【目的】要知医科大学䎵尿器科にて治療を行った膀胱上皮 内癌(CIS)症例の臨床病理学的検誩を行うと共に、上皮異形 成 (dysplasia)との関連性について解析を試みた。

【対象方法・結果】1976年〜1995年までの20年間に当科に おいて治療が行われた膀胱癌のうち、経尿道的生检標本あ るいは傽胱全摘除標本にてCISが頨められた49例（39〜77 歳、平均62歳、男40例、女9例) を対象に臨床的検討を行 った。CISの内訳は原発性17例、続発性3例、随伴性29例で あり、随伴性CISでは主腫瘍の発育様式、組織学的異型度、 組䄉学的梁達度との関連性、主腫演とCISの連続性について 㛟討を行った。又、CIS49例中17例 $(34.7 \%)$ に同時に dysplasiaが認められたが、CISとdyplasia㧍よび随伴 性CISの場合主腫場とdysplasiaの関連性についても㛟討 した。治療法に関しては、49例中26例に倿胱全摘除術、23 例に傽胱保存療法(BCG湾胱内注入14例、ADMあるいは THP-ADM勎胱内注入7例、TUR2例）が初回治療として行わ れたが、各治療法およびその問題点、膀脂保存療法後にCR が得られた症例における再発、病期進展、予後について併 せて検討を行い若干の知見を得たので報告する。

\section{P - 331 膀胱全摘100例の臨床統計 群馬大学 ${ }^{11}$ - 足利赤十字 ${ }^{2}$ \\ 橋本勝善 ${ }^{1)}$ - 岡崎浩 ${ }^{1}$ ・ 川島清隆 2 - 今井強—1 ・山中英寿}

【日的】膀胱全摘術施行症例の治療成績及び予後因子の 検討

【対象と方法】1975年1月から1994年5月までに、群馬大 学泌尿器科において膀胱全摘術を施行した新鮮膀胱癌の 100例を対象とし、治療成績と病理所見との関係をみた。 生存率はKaplan Meier法により算出した。

【結果】年齢は30歳から90歳 (平均66.26歳)、性別は男 性79例、女性21例、経過観察期間は6日から7541日（平 均2016日）であり、30例の癌死を認めた。全体の累積 生存率は 1 年 $70.4 \% 、 3$ 年 $56.4 \% 、 5$ 年 $48.2 \%$ であった。 癌死は3年以内に集中しており、その多くは遠隔転移が 原因となっていた。病理学的には、移行上皮癌が83例、 移行上皮癌亡腺癌などの合併が12例、それ以外が5例で あった。異型度はG1 4例、G2 24例、G3 67例であっ た。深達度別の癌死はpTa以外の症例にみられた。pT2 以上、壁内静脈侵襲 (+)、浸潤様式INF $\beta 、 \gamma$ の症例は 予後不良の傾向があった。また、放射線療法や化学療法 を受けたものの方が予後不良の傾向があったが、これは 背景因子の相違によるものと思われた。

【結話】以上より、膀胱全摘症例の予後因子としては、 深達度、壁内静脈浸潤の有無、浸潤様式が重要であり、 転移を予防する補助療法の開発が必要と思われた。

\section{P -330原発性膀胱癌に対する膀胱全摘除術の臨床 病理学的検討

\begin{tabular}{|c|c|}
\hline 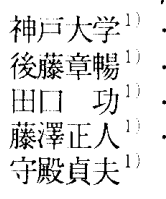 & 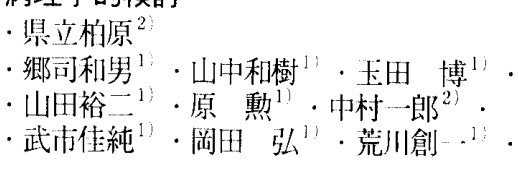 \\
\hline
\end{tabular}

[目的] 原発性膀胱癌に対寸る膀胱全摘除術は、近年の抗癌 化学療法や放射線療法の進歩にもかかわらず、最も有用な治 療法と考えられている。今回、我々は膀胱全摘除術を施行し た原発性膀胱癌の臨床病理学的検討を行つた。対象および結 果] 1986 年1月から 1995 年12月までの10年間に 神三大学医学部附属病院泌家器科で膀胱全摘除術を施行した 原発性膀胱癌 56 例 (男性 48 例、女性 8例) である。年歯 は4 3 歳から 79 藏 (平均 63.6 歳)であった。病理組織は 全例移行上皮癌で、うち 6 例で扁平上皮癌抢よび 2 例で腺癌 の混在を認めた。また、その異型度はG1が6例、G2が29 例、G3が 21 例で、病理学的深達度は p T0が 3 例、p T 1 が 15 例、p T2が 12 例、 p T 3が 21 例、 p T4が5例であっ た。所属りンパ節転移を 8 例に認めた。膀腅全摘除術後の尿 路変更として、尿管皮膚㾇、回腸導管、Hautmann、modified Studer、Mainz、Goldwasser、modified Reddy法などか行なわれた。 M-VAC療法を主体とする neoadjuvant療法が 20 例、 adjuvant 㙩 法が18例に行なわれた。全症例のKaplan-Meier法による1年、 3 年抢よび 5 年生存率は备 $92 \% 、 73 \% 、 62 \%$ $\%$ であうた。 また p T別 5 年生存㸉は p T0が $100 \%$ 、 p T1が $96 \%$ 、 p T2が7 1\%、p T3が57\%および p T4が4 8\%であった。 リンパ節転移有無別 3 年生存辩は p N (.) が $82 \% 、 p N$ (+) が $31 \%$ であった。結語]p T3以上および p N (+)の 進行例では膀胱全摘除術だけでなく、その子後改善のためよ り強力な化学療法、放射線療法含吉集学的治療の必琶性が 示㖫された。

\author{
草津中央1) - 滋賀(医大 ${ }^{2)}$ \\ 尾松 操1) - 友吉唯夫2)
}

【目的】エンドセリン (ET)の腎臓での重要な役割を解 明するために, ETの前駆体ペプチドであるBig ET-1, Big ET-2, Big ET-3と成熟型ET(mET)およびET 受容体 に対する抗体をもちい，腎臓におけるETの組織学的局 在を免疫組織化学的手法により明らかにするとともに， ETの分泌と作用機構につき考察する。

【方法】成熟ラットを灌流固定したのち摘出した腎臟 をゼラチン包埋し、凍結切片を作成。1 次抗体と反応 させたのち、ABC-peroxidase法をもちい、DABで発色 させた。

【結果】Big ET-1, Big ET-2, Big ET-3, mETs, ET受容体 の免疫反忘は、おもに系球体メサンギウム細胞, 皮質 部近位尿細管と髄質内帯部集合管に認められた。また 骨道質外帯部集合管と乳頭管にも陽性反応が散見された。 【考察】Big ETとmETが同様の分布をとることから腎 臓においてETはおもに系球体や尿細管系で合成され， 成熟型ペプチドに変換されてから分泌されることが明 らかとなった。さらにET受容体もほほ同じ分布をとる ことから、ETは腎臓においても局所ホルモンとして autocrine / paracrine様式で作用していることが推定さ れた。 